\title{
Planning of City Transportation Infrastructure Based on Macro Simulation Model
}

\author{
Joni Arliansyah", Muhammad Rizky Prasetyo", Astri Yuli Kurnia ${ }^{\#}$ \\ ${ }^{*}$ Department of Civil Engineering, University of Sriwijaya, \\ Jl. Raya Palembang-Prabumulih KM 36, Inderalaya South Sumatera, 30602, Indonesia \\ E-mail: joniarliansyah@yahoo.com,rizkyprasetyo9a@gmail.com,aztri_zainuddin@yahoo.com
}

\begin{abstract}
Palembang City having an area of $358.55 \mathrm{~km}^{2}$ with a total population of approximately 1.8 million people is one of the main cities in Indonesia. A city transport modelling is important in a city transportation planning particularly to overcome the existing transportation problem such as traffic congestion. In this study, Palembang City transportation model was developed using the PTV Visum Program whose transportation modelling was based on the four-step model of transportation. The result of the study shows that the developed model has an excellent reliability in representing the transportation conditions in Palembang and it also indicates that Palembang required bridges connecting between Ulu and Ilir areas of Palembang to overcome traffic congestion in Palembang City. Ideally, in 2022 Palembang will have had 4 connecting bridges and 5 bridges in 2027. The construction of an additional bridge helps to reduce the traffic load on the existing bridge (Ampera), which was built in 1965 and helps spread the traffic load in the city of Palembang
\end{abstract}

Keywords — transport modelling; visum; trip assignment; infrastructure

\section{INTRODUCTION}

Planning and constructing transportation facilities and infrastructures quite influence the increase of economic growth in supporting the achievement of the development target of a country that will have a real impact on the constructive change in the community in all aspects of life. In addition, environmental situation and condition go through a fundamental change to a better and a more progressed improvement that the community standard of living gets increased.

The fact shows that in big cities in Indonesia the needs of transport mobility for people and goods both in the present and future conditions is not matched yet by the provision of planned and sufficient transport facilities and infrastructures that the social and economic activities are still hampered by transport problems such as disorder, ineffectiveness, and inconveniences of public transportation, traffic jam at roads and intersections, etc.

Structuring the network of roads and bridges is an important public issue to be concerned with, given in Palembang City congestion has become prevalent, even it spreads to almost all roads and occurs not only at peak hours only. Traffic jams enormously affect the lives of citizens resulting in a reduced performance of the city's economy, waste of time and energy as well as increased air pollution that in the long term it will interfere with the overall economy.

Transport modelling was used to predict the condition of the road network in the study region, both with and without the development of the network of roads and bridges. Indicators-the traffic predicted from the road transport models such as traffic flow segment, road speed, and the travel time, are usually used to perform a feasibility study of the development plan to be undertaken.

As a metropolitan city as well as the capital of South Sumatra Province, Palembang becomes the centre of government, trade, industry, and settlement in South Sumatra. Good planning of transportation system should have been implemented in order to be able to solve transportation problems commonly occurred in big cities, one of which is traffic congestion.

In this study, the transport modelling of Palembang City used macro-simulation of PTV Visum 15.00 to find out the pattern of movement, search for alternative solutions in order to be able to decipher this congestion and control the distribution of the movement of every trip occurring in Palembang City.

The PTV Visum Program applied four-step transportation modelling. The resulting model reliability was conducted by comparing the traffic volume resulted from the modelling and the one from the field survey. The analysis focused on 
the adequacy of bridge construction plans in Palembang City as outlined in the general plan of spatial Palembang City. The city is divided into two parts by Musi River, that is the Ulu and Ilir areas which are connected by the Ampera Bridge.

\section{MATERIAL AND METHOD}

\section{A. Macro-Simulation Program Used}

Transportation model of Palembang City was developed using a program of macro-simulation of PTV Visum 15.00.Visum is software for simulation macroscopic traffic flow and developed by PTV (Planning Transport Verkehr AG) in Karlsruhe, Germany. It can analyse the macro traffic simulation modelling with various methods of analysis.

In this study, the model was developed using four steps of transportation [1], [2], [3], [4]. Briefly, the making of traffic model using the program of PTV Visum 15.00 [5], [6], [7] is as follows:

1) Establishing road networking of Palembang City in the PTV Visum 15.00.

- Creating a base map of the road network.

- Validating the base map in accordance with the road network in the existing condition.

- Creating an additional road network in accordance with the existing condition.

- Checking directions, rows, lanes, and transportation system of each road network in accordance with the existing condition.

- Creating link paths to ensure that the road network has been linked and it is ready to run the program.

2) Creating an analysis zone of road networking of Palembang City made previously.

- Determining the boundary of analysis zone in accordance with the administration map of Palembang City.

- Dividing analysis zone to determine centroid zone for each analysis zone.

- Creating linking connectors from centroid zone to nodes or entering lanes into the nearest road network with analysis zone.

3) Determining the analysis setting beginning from demand data, the setting of time analysis, demand segment, and procedural sequence in the program of PTV Visum 15.00 .

The steps of model development are shown in Fig. 1. Several successful studies using Visum Program in transportation macro analysis were published [8], [9], [10], [11].

\section{B. Methodology}

Workflow in transportation modelling of Palembang City is shown in Fig. 2.

In analysing the transportation modelling, there are some parameters that can be used. The making of the modelling and the needed data input are as follows:

1) Fixed parameter including a link, zone, connector, PrT path, and nodes.

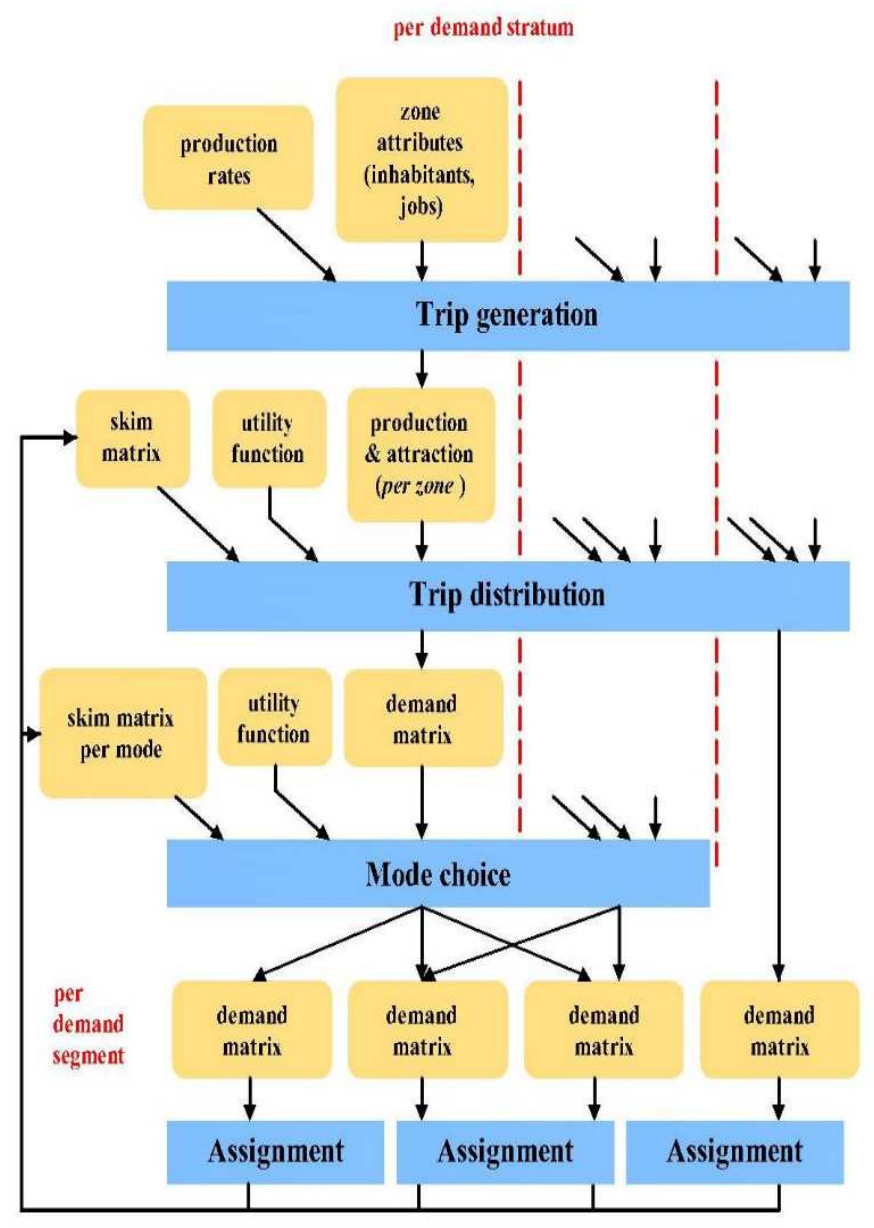

Fig. 1 Integrated 4-step model in visum

2) Independent parameters including the geometric width of the road, maps, background, matrix input, and demand data.

After inputting the above parameters, the modelling output obtained are as follows:

- Desire line trip of each zone.

- Visual trip route load of each Link.

- Results of load analyses in the form of tables.

The methodological procedure of the study is described as follows:

1) Secondary data collection covers collecting of matrix data of destination origins of the previous study [12], [13], whose data needed to the concerned institutions as follows:

- The population of study zone.

- Mode division, transport cost, and fare.

- Data of groups, organizations, and transportation operators in Palembang City.

- General city spatial plan.

- Development of facilities and infrastructures to be executed.

- A network map of city roads and rivers, status, and function of the road, river transport, land use, topography, sub-districts.

- Social demography, economy, industrial and agricultural regions, work sites, and a parameter of regional revenue. 


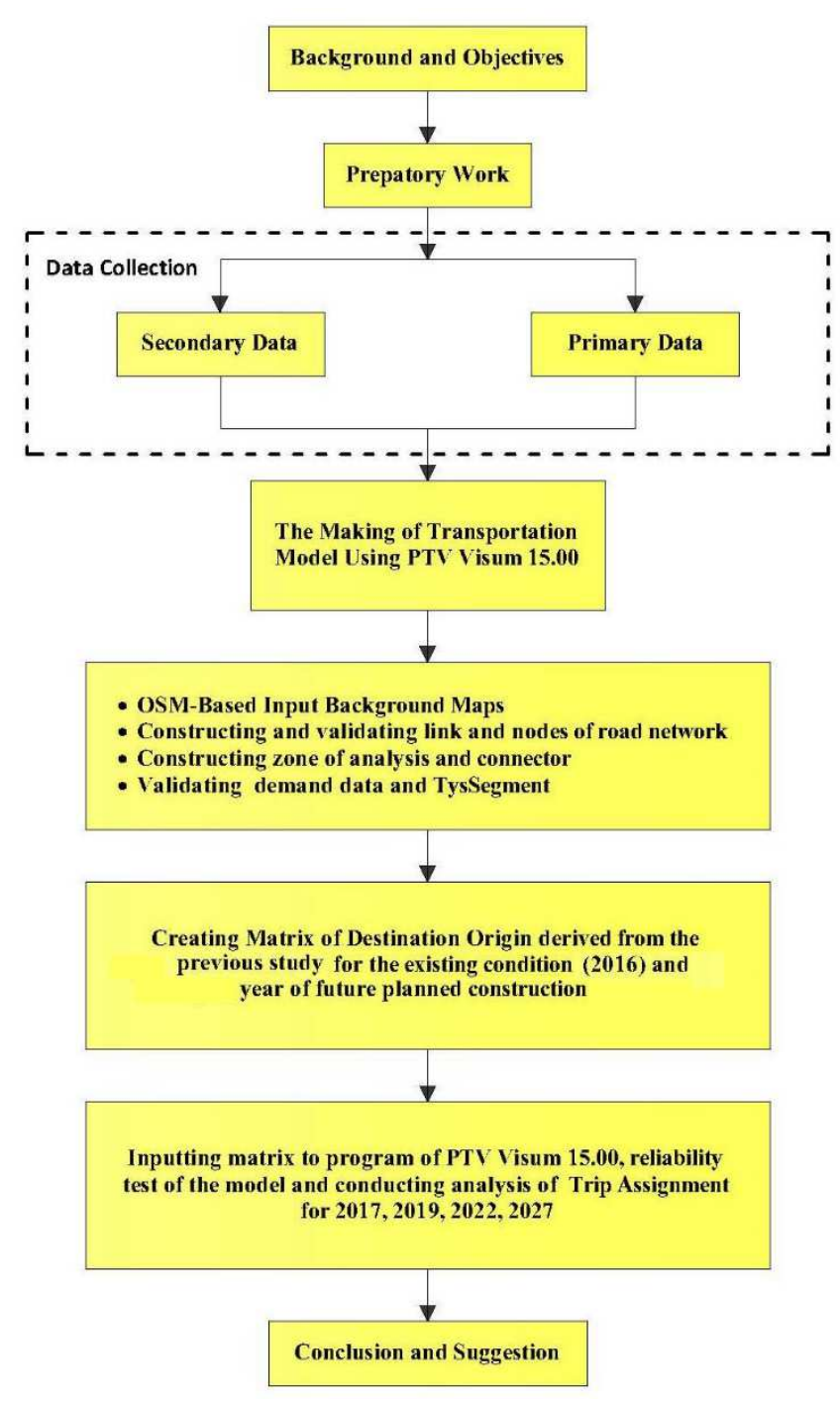

Fig. 2 Research methodology

- Data of traffics, river transport routes, public transport routes, buses, trucks, traffic directions, ownership of vehicles, public transport facilities, facilities of parking lots and traffic, traffic accident data.

- Inventory data of roads, ports and their facilities, terminals, harbours, airports, train stations.

- Data of previous studies

2) Primary data collection covers collection of traffic data of city main road segments and survey of identification of road segments as parts of modeling road network.

3) The matrix of the origin of destination obtained from the previous study [12], [13] was used to predict the OD matrix of 2016 and other matrices for the analysis. Figure zones and road network in the study area are shown in Fig. 3 and Fig 4. It shows that the city of Palembang is split into two parts by the Musi River.

4) Analysis of movement distribution of matrix OD used Detroit method and trip assignment model used the trip assignment of User Equilibrium.

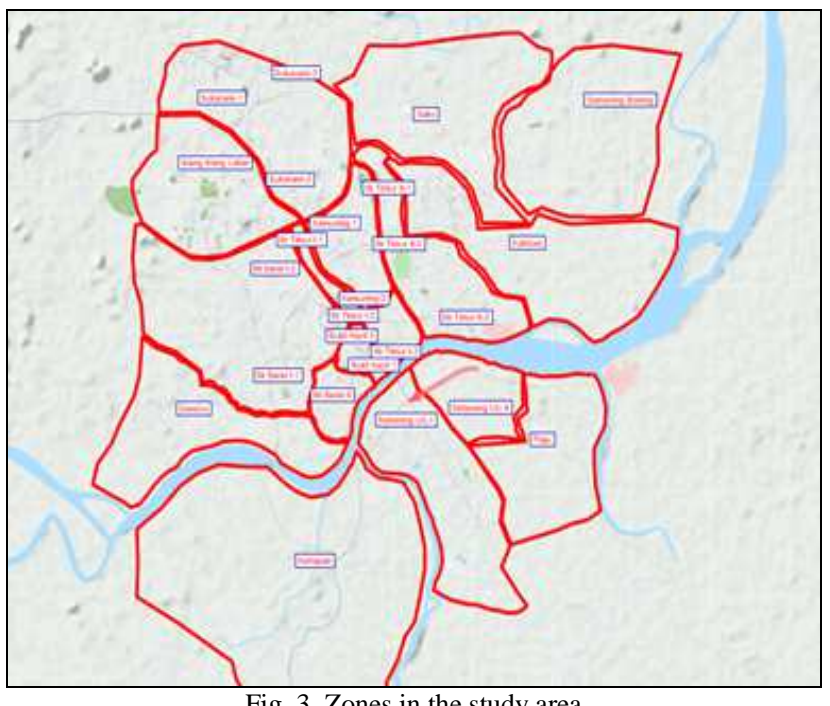

Fig. 3 Zones in the study area

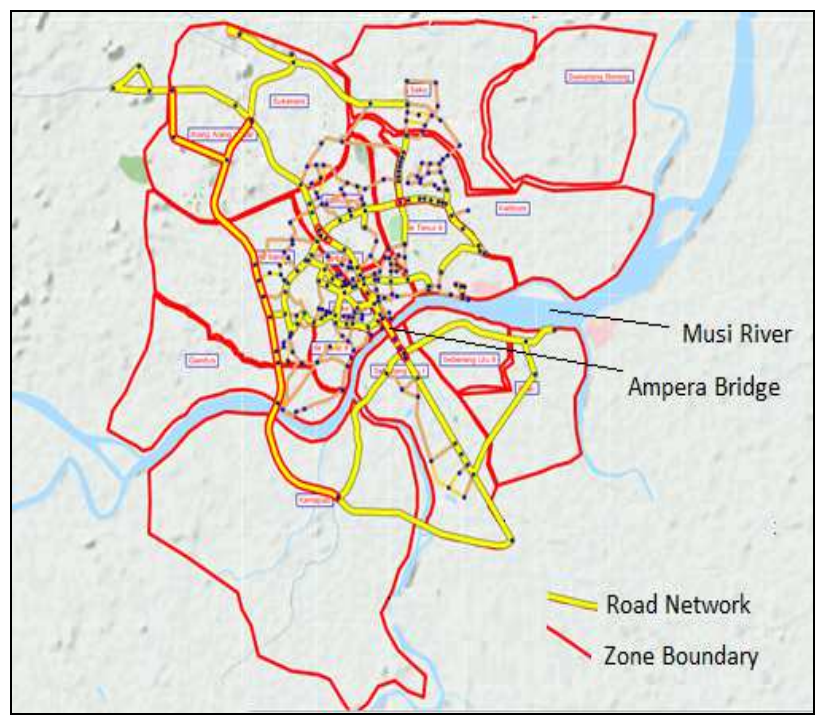

Fig. 4 Road network in the study area

Analysis of the trip route loading is the last phase of identifying how much loading is accommodated for each existing trip route. The traffic loading is the last phase of the four transportation plans which become the selected routes in conducting a trip from one zone to another zone. The selected route is the one which travelling time is the fastest or the cheapest one.

Trip assignment model used a loading model of equilibrium assignment, taking into account of route capacity in which the traffic volume in the network will affect the travelling cost of each route and all travelers are interactively aware of the cheapest route so that they will distribute themselves to each route until all routes have travelling costs.

5) The model reliability was conducted by comparing the results of a survey on road segments and the results of modelling using Visum Program.

6) The developed model was used to analyze the conditions and needs of road and bridge development in Palembang City. The bridge needs analysis refers to Palembang spatial planning shown in Table 1 and Fig. 5. 
TABLE I

SCENARIO OF NETWORK DEVELOPMENT

\begin{tabular}{|c|l|c|}
\hline No & \multicolumn{1}{|c|}{ Scenario } & $\begin{array}{c}\text { Operational } \\
\text { Year } * \text { ) }\end{array}$ \\
\hline 1 & Plan of Construction of Musi 4 Bridge & 2017 \\
\hline 2 & Plan of Construction of Musi 6 Bridge & 2019 \\
\hline 3 & Plan of Construction of Musi 3 Bridge & 2022 \\
\hline 4 & Plan of Construction of Musi 7 Bridge & 2027 \\
\hline
\end{tabular}
with the concerned institution.

\section{RESULTS AND DISCUSSION}

\section{A. Traffic Conditions of Palembang City in 2016}

The volume and service condition of the main road segments of Palembang City being surveyed is given in Table 2 and Fig. 6. It can be seen that:

- There are two road segments during rush hour having exceeding road capacity.

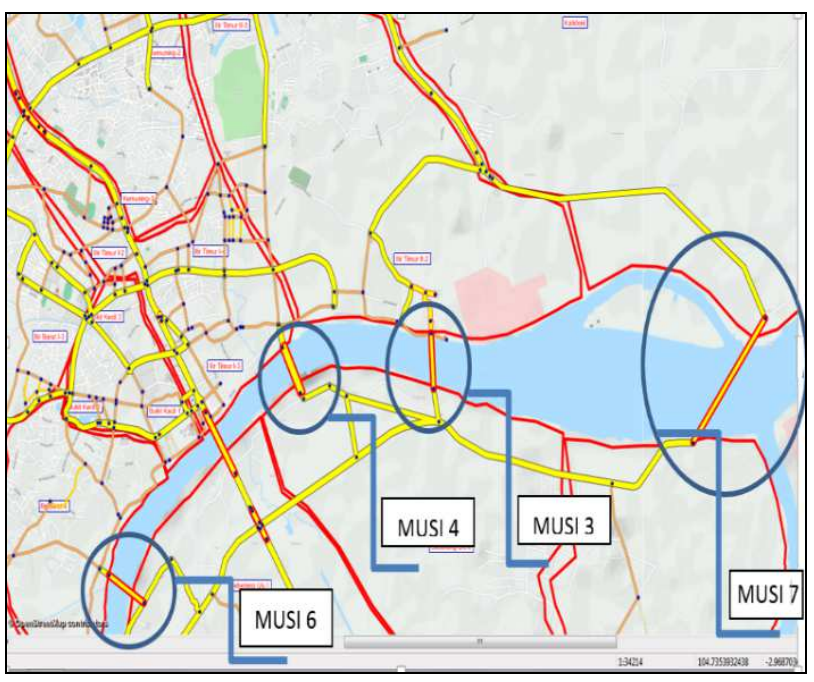

Fig. 5 Bridge development plan in Palembang City

- There are five segments which are already near the capacity during rush hour.

TABLE II

TRAFFIC VOLUME RESULTED FROM SURVEY AND MODELLING

\begin{tabular}{|c|c|c|c|c|c|c|}
\hline No & Name of Street & $\begin{array}{c}\text { The Owner of } \\
\text { Road }\end{array}$ & Capacity & $\begin{array}{c}\text { Survey Result } \\
(\mathbf{s m p / h o u r )}\end{array}$ & V/CRatio & $\begin{array}{c}\text { Result of Trip Assignment } \\
\text { Analysis (smp/hour) }\end{array}$ \\
\hline 1 & POM IX & City & 4007 & 3367 & 0.840 & 3245 \\
\hline 2 & Angkatan 45 & Province & 4356 & 2328 & 0.534 & 2832 \\
\hline 3 & $\begin{array}{c}\text { Kapten A. Rivai } \\
\text { (East) }\end{array}$ & Province & 3630 & 2636 & 0.726 & 2725 \\
\hline 4 & $\begin{array}{c}\text { Kapten A. Rivai } \\
\text { (West) }\end{array}$ & Province & 4356 & 2858 & 0.656 & 2648 \\
\hline 5 & Radial & City & 4007 & 2879 & 0.718 & 4243 \\
\hline 6 & R. Sukamto & National & 4356 & 4826 & 1.108 & 2736 \\
\hline 7 & Abdul Rozak & National & 4704 & 2766 & 0.588 & 7182 \\
\hline 8 & Mangkunegara & Province & 6703 & 7803 & 1.164 & 4803 \\
\hline 9 & AKBP Cek Agus & National & 3240 & 2638 & 0.814 & 4653 \\
\hline 10 & Kol H Burlian & National & 4950 & 4199 & 0.848 & 2819 \\
\hline 11 & Soekarno Hatta & National & 5346 & 2149 & 0.402 & 3576 \\
\hline 12 & $\begin{array}{c}\text { Kol H Burlian } \\
\text { (km12) }\end{array}$ & National & 4554 & 3129 & 0.687 & \\
\hline
\end{tabular}

TABLE III

Condition OF BRIDGe SERVICE LEVEl IN PALEMBANG UP TO 2027

\begin{tabular}{|c|c|c|c|c|c|c|c|c|c|c|c|c|}
\hline \multirow{3}{*}{ No } & \multirow{3}{*}{$\begin{array}{l}\text { Bridge } \\
\text { Name }\end{array}$} & \multirow{2}{*}{ Capacity } & \multicolumn{2}{|c|}{2016} & \multicolumn{2}{|l|}{2017} & \multicolumn{2}{|c|}{2019} & \multicolumn{2}{|l|}{2022} & \multicolumn{2}{|l|}{2027} \\
\hline & & & Volume & $\mathrm{V} / \mathrm{C}$ & Volume & $\mathrm{V} / \mathrm{C}$ & Volume & $\mathrm{V} / \mathrm{C}$ & Volume & $\mathrm{V} / \mathrm{C}$ & Volume & $\mathrm{V} / \mathrm{C}$ \\
\hline & & (smp/hour) & (smp/hour) & & (smp/hour) & & (smp/hour) & & (smp/hour) & & (smp/hour) & \\
\hline 1 & $\begin{array}{l}\text { Ampera } \\
\text { (Existing) }\end{array}$ & 5742 & 11237 & 1.96 & 6269 & 1.11 & 5450 & 0.95 & 4401 & 0.77 & 4201 & 0.73 \\
\hline 2 & Musi 4 & 5742 & & & 5267 & 0.92 & 2982 & 0.52 & 3412 & 0.59 & 3287 & 0.57 \\
\hline 3 & Musi 6 & 5742 & & & & & 7175 & 1.25 & 6632 & 1.15 & 3648 & 0.64 \\
\hline 4 & Musi 3 & 5742 & & & & & & & 3480 & 0.61 & 2527 & 0.44 \\
\hline 5 & Musi 7 & 5742 & & & & & & & & & 4623 & 0.81 \\
\hline
\end{tabular}




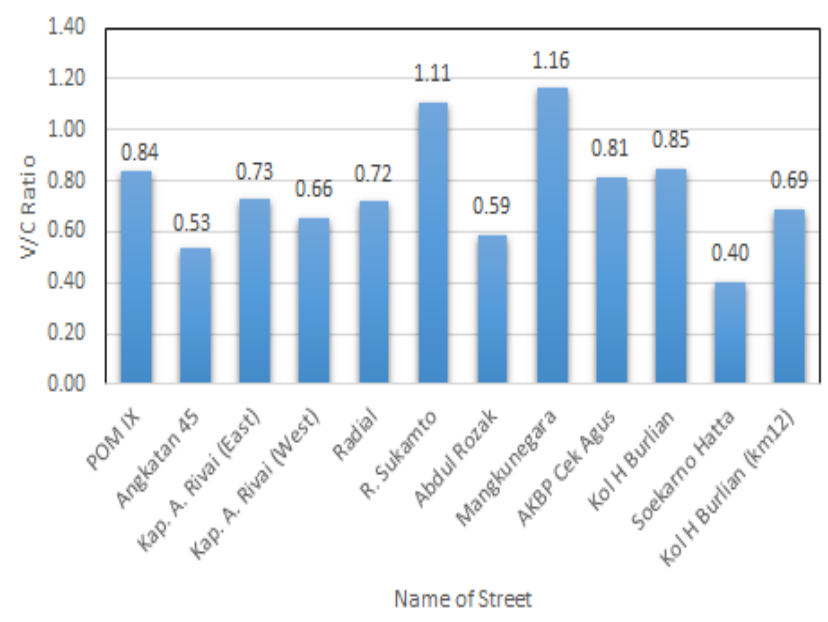

Fig. 6 V/C ratio of existing road

The above matters indicate that during rush hours most main road segments in Palembang City have a poor service level.

\section{B. Model Reliability}

The model reliability test was carried out by comparing the traffic volumes of 12 main road segments of Palembang City with the result of modelling in 2016 shown in Table 3 and Fig. 7. The resulting model can well represent the traffic conditions of Palembang City with the $\mathrm{R}^{2}$ value of 0.836.After conducting a reliability test of the model, it was proceeded to analyse the traffic conditions of Palembang City using the developed model, in this case, the analysis of the adequacy of the number of bridges crossing the Musi River.

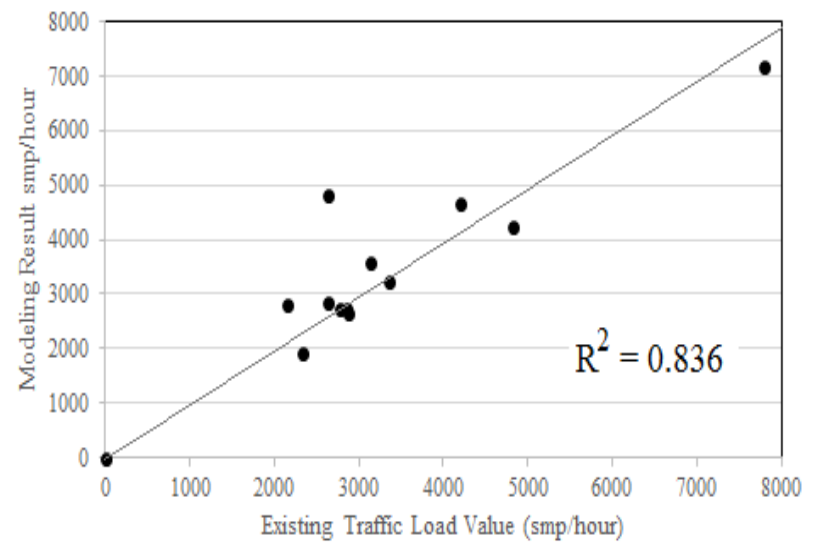

Fig. 7 Correlation analysis between the existing traffic and modelling result

\section{Analysis of Bridge Construction Adequacy}

In accordance with the spatial plan of Palembang City [14] until 2027, Palembang City will construct four additional bridges, namely Musi 4 Bridge, Musi 6 Bridge, Musi 3 Bridge, and Musi 7 Bridge. The analysis was carried out to see if the plan of bridge constructions met the movement needs in Palembang City. Table 3 shows the results of Visum program for bridge service rate in Palembang in 2017, 2019, 2022, and 2027. The analysis results of needs adequacy of bridge constructions in Palembang is as follows:

- In the existing year of 2016, the Ampera Bridge as the only bridge connecting the Ulu and Ilir areas of Palembang cannot serve the existing traffic movement anymore. It also causes traffic congestion on road network in Palembang City particularly on the main roads directly connected to or affected by the performance of the Ampera Bridge.

- Even though there will be an additional construction of Musi 4 Bridge in 2017, the existing two bridges still serve the traffic in saturated conditions. Yet, given the short time of constructing of the Musi 4 Bridge which has not started yet until now, it is estimated that the bridge construction in 2017 will be difficult to complete.

- In 2019 even though there are two additional constructed bridges, two of the three existing bridges at rush hours are at saturation. It indicates that the constructions of the 2 bridges need to be conducted until 2019. Late constructions will result in severe congestion in Palembang City.

- In 2022 the addition of three new bridges is quite ideal for servicing the traffic between Ulu and Ilir areas of Palembang City though one bridge still has saturated conditions during rush hours.

- In 2027 it will have had at least 5 connecting bridges to well serve the traffic movement from Ulu to Ilir areas and vice versa. It shows that in the next 10 years the additional constructions of 5 bridges have to be realized to prevent Palembang City from the congestion problem.

\section{Analysis of Traffic Loading of the Existing Bridge (Ampera)}

Currently, in 2016, Ampera Bridge constructed in 1965 is still the only bridge connecting Ulu and Ilir areas of Palembang City. Shown in Table 3, at rush hour traffic loading exceeds the existing bridge capacity. The needs of the additional bridge are accordance with the existing plan has to be able to realize to reduce the load of Ampera Bridge and spread the traffic movement of Palembang City. Fig.8 shows that the construction of additional bridges between Ulu and Ilir areas helps spread the movement from the Ampera Bridge to the new bridges as well as the traffic movement in Palembang City. The traffic spread from the Ampera Bridge both increases the level of bridge service and decreases loads on the Ampera Bridge structure.

Fig 9. and Table 4 show the decrease of traffic loading on Ampera Bridge if the plan of bridge construction is realized. Fig 8 shows that in 2017 if there is an additional bridge, Musi 4, the traffic load decreases to $55.6 \%$, and with the addition of 3 or 4 bridges in 2022 and 2027, the traffic load on Ampera bridge will become $39.1 \%$ and $37.3 \%$. Table IV shows the movement percentage on the Ampera Bridge against the total movement existing in Palembang City. The percentage decreases to be $2.23 \%$ in 2016 and $1.01 \%$ in 2027. 
TABLE IIIV

MOVEMENTPERCENTAGE ON THE AMPERA BRIDGE AgAinst THE TOTAL MOVEMENT IN PALEMBANG CITY

\begin{tabular}{|c|c|c|}
\hline No & Year & $\begin{array}{c}\text { Movement Percentage on } \\
\text { the Ampera Bridge }\end{array}$ \\
\hline 1 & 2016 & 2.23 \\
\hline 2 & 2017 & 1.46 \\
\hline 3 & 2019 & 1.23 \\
\hline 4 & 2022 & 1.19 \\
\hline 5 & 2027 & 1.01 \\
\hline
\end{tabular}

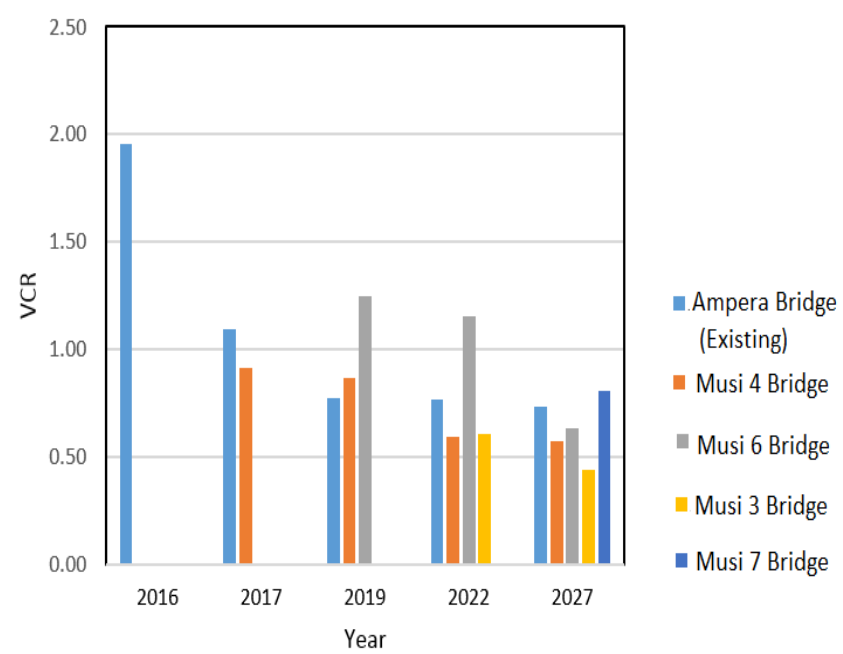

Fig. 8 Service level of bridges

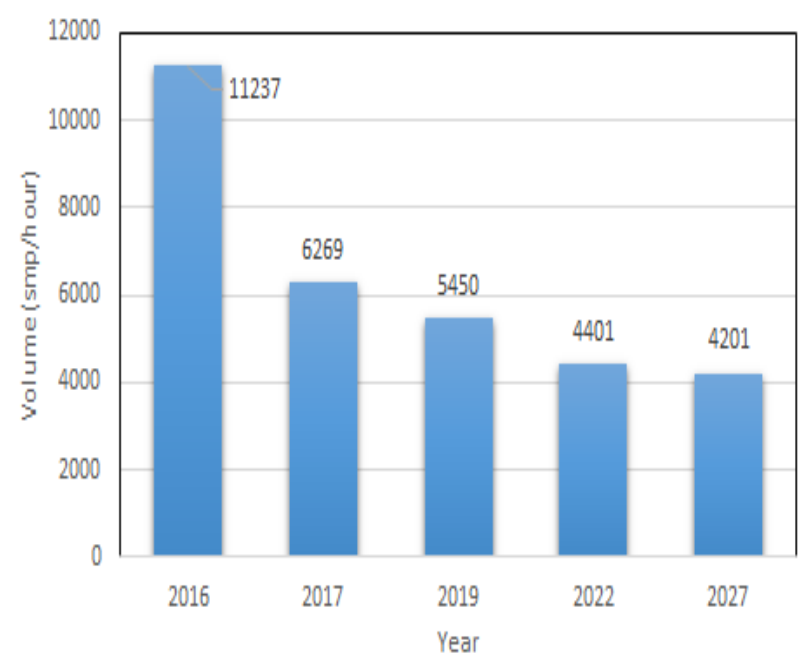

Fig. 9 The Decrease of traffic loading on Ampera Bridge if the plan of bridge construction is realized

\section{CONCLUSION}

Based on the analysis, the conclusions are as follows: The development of transportation model of Palembang City using Visum Program can well represent the transportation conditions of Palembang City. In the existing condition (2016), the existing Ampera Bridge has not been able any more to serve the traffic movement between Ulu and Ilir areas of Palembang City. To serve the traffic between Ulu and Ilir areas of Palembang City, ideally, Palembang City will have had 4 bridges in 2022 and 5 bridges in 2027. The construction of additional bridges in Palembang City could greatly diminish the load of Ampera Bridge that has been used since 1965 and helps spread the traffic in Palembang City.

\section{REFERENCES}

[1] O. Z. Tamin, Planning, Modeling and Transport Engineering, Bandung ITB Publisher, 2008.

[2] J.W. Dickey, Metropolitan Transportation Planning, 2nd ed.,Taylor \& Francis Publisher, 1983.

[3] M.D. Meyer and E.J. Miller, Urban Transportation Planning, 2nd ed., Mc Graw Hill, 2000.

[4] W. R. Black, Transportation - A Geographical Analysis, 1st ed.,The Guilford Press, 2003.

[5] PTV AG, PTV Visum Manual, Karlsruhe, Germany, 2015

[6] PTV, Visum State of The Art Travel Demand Modeling, [Online]. Available: http://data.ptvamerica.com/docs /Visum.pdf

[7] PTV Groub, PTV Visum Tips \& Tricks, [Online]. Available: http://vision-traffic.ptvgroup.com/en-us/training-support/ support/ ptv-visum/tips-tricks/

[8] I. Yatskiv and M. Savrasov, Development of Riga-Minsk Transport Corridor Simulation Model, Journal of Transport and Telecommunication, 1 (2010) 38-47.

[9] S. Fierek and J. Zak, Planning of Integrated Urban Transportation System Based on Macro - Simulation and MCDM/A Methods, Procedia - Social and Behaviour Sciences 54 (2012) 567-579.

[10] M. Kontelj and I. Jakomin, Transport Modelling of Freight Flows in Accordance with Investments: Case Study of Slovenian Railways, Promet-Traffic \& Transportation, 26-5 (2014) 429-436.

[11] E. Mitsakis, G. Aifadopoulou, J. M. S. Grau, E. Chrysohoou and M. Morfoulaki, Combination of Macroscopic and Microscopic Transport Simulation Models: Use Case In Cyprus, International Journal for Traffic and Transport Engineering, 4-2 (2014) 220-233.

[12] J. Arliansyah, E. Nursalam, M. Yusuf, and M. Agustine, Study Development of Transportation Infrastructures in Palembang In Order To Achieve Optimal Urban Transportation Services (First year), Final Report of National Strategic Research, 2009.

[13] J. Arliansyah, E. Nursalam, M. Yusuf, and M. Agustine, Study Development of Transportation Infrastructures in Palembang In Order To Achieve Optimal Urban Transportation Services (Second year), Final Report of National Strategic Research, 2010.

[14] Bappeda Palembang, Palembang Spatial Planning, 2010. 